\title{
Where feminists dare: The challenge to the heteropatriarchal and neo-conservative backlash in Italy and Poland
}

\author{
OÑATI SOCIO-LeGAL SERIES Volume 10, ISSUE $1 S$ (2020), 38S-66S: THE FOURTH WAVE OF FEMINISM: \\ FROM SOCIAL NETWORKING AND SELF-DETERMINATION TO SISTERHOOD \\ DOI LINK: HTTPS://DOI.ORG/10.35295/OSLS.IISL/0000-0000-0000-1156 \\ RECEIVED 22 JANUARY 2020, ACCEPTED 02 MARCH 2020
}

\author{
AGNIESZKA BIELSKA-BRODZIAK* (iD) \\ MARLENA DRAPALSKA-GROCHOWICZ* (D) \\ CATERINA PERONI* (ID) \\ ELISA RAPETTI*
}

\begin{abstract}
* Agnieszka Bielska-Brodziak, an associate professor of the University of Silesia in Katowice at the Faculty of Law and Administration, a practicing lawyer. Interests: 1. theory and philosophy of law, in particular, law-making process and legal interpretation, 2. the interface of law, medicine, and bioethics. Within this area, she is particularly interested in the legal (public and private) consequences of legal, biological, and gender identity conflicts. She studies two groups of entities: transgender and intersex people. She is a member of an interdisciplinary medical and legal group working on improving standards of care for underage and transgender patients as well as changing Polish law in the field of gender recognition. She is a Head of Unit UNESCO Chair in Bioethics at the University of Silesia. She participates in the project HERA Healthcare as a Public Space: Social Integration and Social Diversity in the Context of Access to Healthcare in Europe. Contact details: University of Silesia in Katowice, Faculty of Law and Administration, ul. Bankowa 11, Katowice, Poland. Email address: agnieszka.bielska-brodziak@us.edu.pl

* PhD candidate in the Department of Theory and Philosophy of Law in the Faculty of Law and Administration of University of Silesia in Katowice. Her research interests include legal psychology, Law\&Emotions approach, vulnerability group's status. She realizes a scientific grant from the National Science Center on the subject "Reconstruction of the closeness category in the Polish legal system." As part of the project, she examines a relational approach in law, in particular, the meaning and importance of close interpersonal relationships in law from philosophical and psychological perspectives. Contact details: University of Silesia in Katowice, Faculty of Law and Administration, ul. Bankowa 11, Katowice, Poland. Email address: mdrapalska@gmail.com

* Research fellow at the IRPPS-CNR ViVa project - Monitoring, Assessment and Analysis of the Measures to Prevent and Fight Violence against Women and coordinator of the module on "Feminist Criminologies and intersectionalities" of the Master in Critical Criminology at the University of Padua. Her main fields of research, teaching and study are the feminist studies in the field of gender-based violence, trafficking and prostitution, sexual and reproductive citizenship, discrimination of LGBTQI subjectivities included the criminal field, and of the production of discourses and practices of feminist and trans-feminist movements. Contact details: IRPPS - CNR, via Palestro 32, 00185 Rome (Italy). Email address: caterina.peroni@irpps.cnr.it ${ }^{*} \mathrm{PhD}$ in Methodology of Social Research and Applied Sociology. Her research interests include gender discrimination, citizenship and education, learning and teaching processes. Her involvement into international development cooperation projects as consultant for several NGOs has led her to focus on how gender is intersected with ethnicity, class, age and other axis of social differentiation and discrimination. Her professional skills include designing, implementing and monitoring gender training courses. Contact details: Vicolo Fontana, 7 - 15010 Gamalero (AL), Italy. Email address: rapetti.elisa@gmail.com
\end{abstract}




\section{Abstract}

This paper focuses on the public debate in Poland and Italy concerning the right to abortion in the contemporary rise of populist neo-conservative forces in Europe and of a global feminist movement. In both countries, the historical Catholic interference into women's reproductive rights and self-determination has been enforced by the renewed alliance of right-wing governments and pro-life groups to converge into a transnational "anti-gender war". This represents a real backlash against women's achievements over the last decades in terms of reproductive and sexual citizenship, which appears to be the battlefield for redefinition of western citizenship in times of global crisis. Although different genealogies, we identified a common framing of neo-conservative discourse, and of feminist claims and practices, as that of feminist strikes and social mutualism. In this perspective, we consider these practices as a normativity from below, arguing that feminist movement is addressing a new paradigm of citizenship.

\section{Key words}

Anti-gender movements; backlash; abortion; Black Monday; feminist strike; Non Una Di Meno

\section{Resumen}

Este artículo se centra en el debate público en Polonia e Italia acerca del derecho al aborto, en medio del auge de fuerzas populistas neoconservadoras en Europa y de un movimiento feminista global. En los dos países mencionados, la interferencia que se ha dado históricamente desde el catolicismo a los derechos reproductivos y la autodeterminación de las mujeres ha quedado reforzada por una renovada alianza de los gobiernos de derechas y de los grupos provida, la cual ha convergido en una "guerra antigénero" transnacional. Esto representa una reacción contra los logros de las mujeres en las últimas décadas en cuanto a ciudadanía reproductiva y sexual, que parecen ser el campo de batalla donde se redefine la ciudadanía occidental en tiempos de crisis global. Pese a las diferentes genealogías, hemos identificado un marco común del discurso neoconservador, y también de las reclamaciones y prácticas feministas, en la lucha feminista y el mutualismo social. Desde esa perspectiva, consideramos esas prácticas como una normatividad desde la base, pues argumentamos que el movimiento feminista se está ocupando de un nuevo paradigma de ciudadanía.

\section{Palabras clave}

Movimientos antigénero; reacción; aborto; Lunes Negro; lucha feminista; Non Una Di Meno 


\section{Table of contents}

1. Breeding ground for backlash: the clash for citizenship .........................................41

2. The genealogy of neo-conservative attacks on abortion rights in Poland ...................44

3. The genealogy of neo-conservative attacks on abortion rights in Italy.......................46

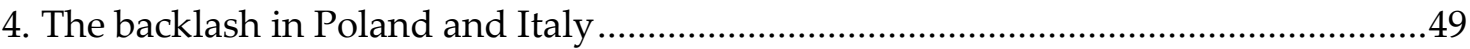

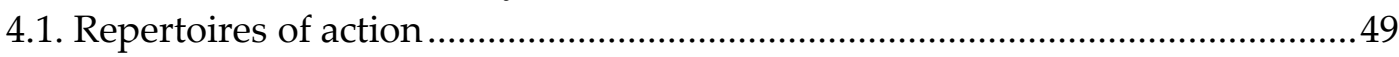

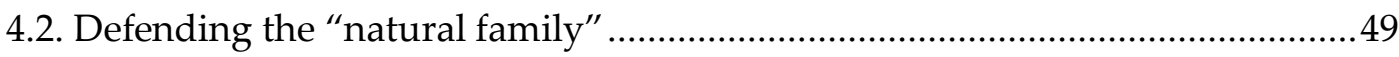

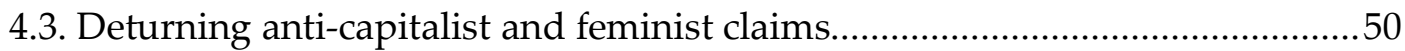

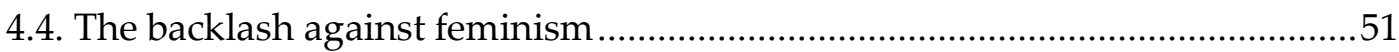

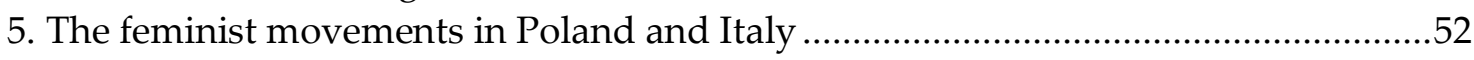

5.1. Resisting the backlash and striking patriarchy .............................................52

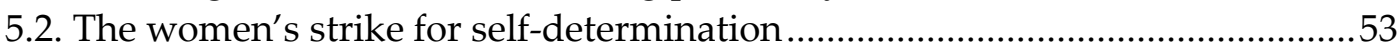

5.3. De-blaming abortion: Women's mutualism for self-determination...................56

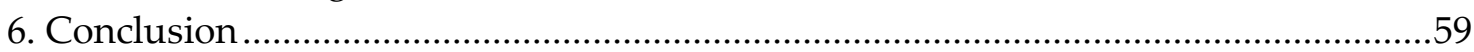

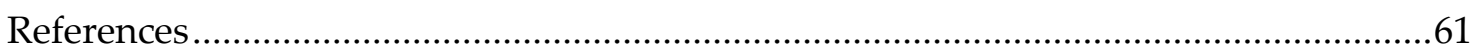




\section{Breeding ground for backlash: the clash for citizenship}

In the last decade, a new wave of neo-conservative attacks against feminist and LGBTQI (lesbian, gay, bisexual, transgender, queer and intersex) rights and freedoms has been fuelled by Catholic and right-wing forces in several post-socialist and Western European countries, converging in what is termed the "War on Gender Ideology" (Garbagnoli 2014, Kuhar and Paternotte 2017, Paternotte and Kuhar 2018, Lavizzari and Prearo 2018). As Kuhar and Paternotte $(2017,2)$ argue, in recent years, the European anti-gender groups and organisations have converged their strategies, sharing "discourses, strategies and modes of action across borders; observ[ing] what each other is doing; and are increasingly connected transnationally" (see also Datta 2018).

This war is addressing sexual and reproductive citizenship rights gained by feminist and LGBTQI movements in recent decades, in order to restore the heteropatriarchal social order represented by traditional family and values. According to several critical and feminist scholars, this war represents the convergence of the neoliberal and heteropatriarchal traits of right-wing populism (Zappino 2016, Kuhar and Paternotte 2017), whose aim is to subordinate sexual, gender, racial and religious differences within the so-called "universal" - white, male, hetero and Christian - citizenship (Bellè et al. 2018). Indeed, the struggles for the extension of sexual rights for LGBTQI people and against patriarchal normativity and discrimination by feminist movements have deeply challenged the idea of citizenship rooted in the Western paradigm of rights (Richardson 2017), by contesting its material, political, gendered and national borders. The neo-conservative backlash contrasts this redefinition of citizenship and its related social and economic rights by excluding non-heteronormative, non-white and nonChristian subjectivities from the welfare state, and by radically limiting women's and LGBTQI people's reproductive and sexual freedoms.

The renewed centrality of heterosexual reproduction in European countries is consistent with the economic crisis and the austerity measures of the early 2000s, which have progressively offloaded the costs of economic and financial cuts on the traditional family as subsidiary to the welfare state (Kuhar and Paternotte 2017). To support this process, the gendered and heterosexual division of productive and reproductive labour has been enforced, constraining women into the symbolic and material role of mothers reproducing the Nation (Hall 2019), and contextually banning same-sex couples from State recognition. The "War on Gender Ideology", waged in recent years by pro-life and Catholic groups, particularly in Western countries (Korolczuk 2016, Salvatori 2018), has supported this process through a virulent form of moral panic (Herdt 2009) aimed at defending the heterosexual family and social order by excluding "sexual 'folk devils'" (i.e. LGBTQI people) from enjoying "universally" recognised citizenship rights (Seidman 2001). In the anti-gender frame, the "phantom of Gender" is represented as a cultural and ideological invasion that colonises the "traditional" culture to destabilise the "natural" family and the reproduction of the species. All these discourses are fuelled by the instrumental and emotional mobilisation around the "defence of a child's innocence" from corruption, in a sort of "moral battle" against decadence (Richardson 2017). For anti-gender actors, defending children's innocence means also defending their lives from a "culture of death" encouraging "divorce, birth control, homosexuality, 
abortion and euthanasia", as stated by the Vatican institution defining Gender Ideology - GI - (Urquhart 1999, Datta 2018).

According to Kuhar and Paternotte (2017), gender theory/ideology is a discursive and strategic device developed in recent years by Catholic groups, aimed at defending the "natural" heterosexual social order against an "ideological colonisation". This device addresses not only reproductive freedom and self-determination of women, but also the rights of sexual minorities and, more generally, the epistemic and political assumptions deconstructing essentialism and the naturalisation of sex and gender (Bellè et al. 2018), i.e. feminist theories and gender studies. In this view, "Gender" as a discourse represents an anthropological question concerning the whole of society, the traditional family and the security of children, confusing the nature of binary sex with the social construction of gender, and imposing the concept of gender mainstreaming - a totalitarian ideology distorting the natural sexual identities. To be under attack is the "human ecology" - a concept issued by Pope Francis to affirm the defence of human nature against abortion, reproductive technologies and transgenderism.

Moreover, the anti-gender movement has allied with the new populist forces rising in many European countries, with which it shares an ideological structure based on the oppositional strategy "them and us" (Mény and Surel 2002, Paternotte and Kuhar 2018), constructing binary identities founded on axiological and normative frames: the "normal majority" vs. the elites (Paternotte and Kuhar 2018, 13). According to Wodak (2015), this rhetoric is informed by a sort of social revanchism due to the economic crisis and the consequent austerity measures in all the European countries, fuelling fear and moral panic against new scapegoats, including sexual minorities. Therefore, in these cases, gender functions act as "symbolic glue" against a common enemy (Kováts and Põim 2015, Datta 2018).

The movement faces off against the "non-scientific lobbies" represented by LGBTQI associations and organisations, which are considered responsible for a cultural invasion of "Gender ideology" in order to indoctrinate children. This use of science and nature is a key element in the discursive strategy in order to justify religious and backward positions about women's and LGBTQI sexuality and rights: nature (and no longer God) becomes the unquestionable source of the institutional, legal and social legitimacy (Braidotti 2008, Scott 2009) of the heteronormative order based on the heterosexual family (Bellè et al. 2018). This discursive strategy is a political and epistemic device aimed at hierarchising genders within family, and therefore in society as a whole, consequently dismantling women's self-determination and feminism itself.

This backlash has seriously affected the political debate in Italy and Poland, two countries belonging to two opposite political traditions (Western and post-socialist), but connected by the strong presence of Catholic forces in the political arena and their structural infiltration in the current neo-conservative governments. Interestingly, in both countries the GI is associated with totalitarian systems, differently inflecting the historical references to dictatorship and authoritarian regimes related to the history of the two countries (Paternotte and Kuhar 2018): in Italy, the GI and the "international LGBTQ lobby" are associated with the "single thought" of Orwell's Big Brother, recalling the opposition to non-Catholic Anglo-Saxon cultural colonisation. This is a typical feature of the Italian far-right discourse and has a double aim: to recall the 
foundational mythology of Rome opposing barbarian non-Catholic cultures, and to detach the idea of dictatorship from the real one that occurred in Italy during fascism, externalising the problem as alien. On the other side, Polish anti-gender discourse relates GI to the violence of the monolithic communist system of thought, in order to put a radical distance between it and the current democracy, and by doing so fuelling a very specific fear and mobilising public opinion against the threat of an actual return of the past (Salvatori 2018, Hall 2019).

Many feminist, queer and transfeminist scholars have argued that the label "Gender Ideology" is a complex ideological manipulation denigrating feminist and gender theories for their deconstructionist critique to the epistemic and political heterosexual dichotomy (Garbagnoli 2014, Zappino 2016, Bellè et al. 2018). In political and social terms, "anti-gender" attacks aim at eroding the achievements in the spheres of sexual freedom and self-determination for women and LGBTQI people, reaffirming the heterosexual norm and the centrality of heteronormative and ethnically cleaned reproduction of Western, white citizens, which are the core of the populist mantra (Hall 2019). Indeed, the transnational mobilisation of women and LGBTQI people, which started in 2016 in the face of gender-based violence, is challenging worldwide the global neo-conservative backlash. It is worth mentioning that this movement started simultaneously in Argentina and Poland, bringing hundreds of thousands of women onto the streets of all continents. The mobilisation started in Argentina in order to fight against the social and institutional impunity of femicide, and against the total ban on abortions being discussed in the Polish parliament.

In the political claims of the movement, a clear link is made between all forms of violence based on gender, described as a paradigm of heterosexual and patriarchal subordination of women and LGBTQI people. In this frame, femicide, homo- and transphobia, sexual and gender discrimination and the ban on abortions are manifestations of the neo-conservative backlash against the last waves of feminist battles. A specific connection between the national expressions of the movement is based on the Catholic context of certain European countries where the Church has historically played a crucial role in building a moral criminalisation of sexual differences and women's self-determination, especially concerning issues like the defence of traditional family and the sacralisation of motherhood. This rhetoric informs policies oriented towards formally supporting the reproductive role of women, while actually aimed at controlling women's and LGBTQI's bodies and choice (Hall 2019).

This connection is clearly visible in the case of Italy and Poland, despite their opposite position along the line of Western/post-Soviet European countries. Indeed, the history of feminist movements in the two countries was very different until the last decade, but has converged with common features during the new wave of mobilisation: the first commonality is the repertoire of action, consisting in the women's social strike, which can be summarised in the slogan If our lives don't matter, then we strike; the second is the intersectional and transgenerational nature of the movements, allowing the message to be put to all women, overcoming resistance and prejudices deriving from previous waves of feminism; the third is the form of "connective actions" (Korolczuk 2016), which took the shape of online platforms of recruitment, organisation, mobilisation and cooperation (Hall 2019). 


\section{The genealogy of neo-conservative attacks on abortion rights in Poland}

Contemporary anti-gender backlashes in Poland and Italy are connected by the recent transnational conservative rising of neoconservative and anti-gender movements. Moreover, they have in common a strong historical influence of Catholic forces on society and political parties. However, Poland and Italy come from different political histories, forming the grounds for the different legalisation on abortion and the ways in which anti-gender forces and feminist movements play on the field of its recognition. These differences are related to two main historical aspects: those belonging to the Soviet and Western spheres during the post-second world war era, as well as the different political and legal strategies adopted by the feminist movements.

In Poland, having an illegal abortion is currently punishable by imprisonment for up to three years (Article 152 of the Criminal Code). The penalty is imposed on a person who, with the woman's consent but against the law, terminates a woman's pregnancy, as well as on anyone who persuades a woman to terminate her pregnancy or helps her to terminate it. The pregnant woman herself is excluded from criminal liability. In 1993, as a result of what is known as the "abortion compromise", a new law introduced a list of conditions for legal abortion, one of which was the pregnant woman's life circumstances or personal situation ("social reasons"). This "social reason" was declared unconstitutional by the Constitutional Tribunal in 1997. Since then, there have been several attempts to change the regulatory framework of the abortion compromise, but all of them have so far failed.

According to Grabowska, the current backlash against women's rights in Poland is a long-term strategy of "re-traditionalising" the post-socialist politics since 1953 and the re-emergence of a neo-conservative and fundamentalist discourse after 1989 (Grabowska 2014, 8, Salvatori 2018). Reforms introduced in 1956 aimed to reconstitute a gendered division of labour, with abortion being liberalised as an attempt to control the number of births within a traditional view of the family. This strategy was seen to be part of the decline in women's rights, introduced in part to strengthen the alliance with the Catholic Church. According to Graff (2010, 16-17), the church "loved democracy and pluralism during communism, then supported this democracy so that, after the Pope's death, it converted to neo-nationalist positions." Since the 1980s, the activity of the Church and pro-life movements has been growing, ${ }^{1}$ affecting the mass media and the political movement of "Solidarity". ${ }^{2}$

In the transition period from 1989 to 1992, the Catholic Church also played an active part in "rebuilding" national identity and civil society (Ramet 2014, 26) within a

\footnotetext{
${ }^{1}$ In the 1980s, the Church and Catholic organizations began more organized activities in the field of abortion: the Church provided organizational support to early meetings of the pro-life movement; the first "crusade of prayers for unborn children" took place Catholic priests began to speak more and more clearly for more restrictive abortion regulations during mass, and "pro-life" activists began organizing exhibitions with photographs of fetuses damaged as a result of abortion combined with the screening of the film Silent Scream (Szelewa 2016, 748).

2 In 1990, at the NSZZ Solidarność National Congress, a resolution was adopted on the protection of life conceived - contrary to the position of trade union activists. In the 1980s, women were a large part of Solidarność, but after the end of the revolution, the male leaders within the union reached a compromise with the Catholic Church, meaning that women's issues became secondary (Salvatori 2018). In the spring of 1991, the Women's Committee in NSZZ Solidarność was dissolved.
} 
"conservative revolution" marked by a pact reached with the new democratic regime (Kulczycki 1995, 472) against communism and women's emancipation. Indeed, both right-wing circles and the Church assumed that the termination of pregnancy was a "communist relic", an expression of the fight against Catholic faith. In this context, Catholic circles and conservative forces made their first attempt to ban abortions in 1989, but the lower house of the bicameral parliament of Poland (the Sejm) rejected it. ${ }^{3}$

The anti-abortion campaign of the Church is, therefore, nothing new, having started during the first "Solidarity" period (Graff 2010, 17). Notwithstanding the widespread of the conservative rhetoric in the public debate, the entry into force of the law of 7 January 1993 caused waves of social protests.

During this phase, Polish feminist politics looked at Western and liberal feminism, referring to non-governmental organisations and academia (Grabowska 2012, Hall 2019), and attracting critics of Western colonisation from within the country. This led to a weakening of feminist struggles for the liberalisation of abortion during the 1990s and 2000s, while women were squeezed out of the political space and their subjectivity was compressed in the nationalist imaginary of the "Polish Mother" (Matka Polka) devoted to reproduction and self-sacrifice (Grabowska 2009, Hall 2019). The portrayal of woman as mother was an important part of the transition process from state socialism (Gal and Kligman 2000). Moreover, this imagery was symbolically validated by the Polish constitution of 1997, which refers to men as citizens and reduces women to mothers (Grabowska 2009, 253-254). In this vein, the repeal of the provision permitting abortions for social reasons in 1997 marked the final point in the public debate on women's freedom and self-determination for several years.

Starting from 2005, documents and statements from leaders of the political party Law and Justice (Prawo i Sprawiedliwość, hereafter PiS) increasingly referred to Catholicism, Christian values and the teaching of John Paul II, focusing on the defence of the traditional family and heterosexuality as a political tool. Since that time, the most important area of activity of pro-life groups has moved on the legal ground - the social activities are aimed at implementing legal changes with the support of the ruling party and individuals holding institutional roles.

On 19 August 2016, again under the ruling PiS party, another draft was submitted by the legislative initiative committee "Stop Abortions" to the Sejm, stipulating - for the first time in Polish history - a total ban on abortions (Voter bill initiative - Sejm paper № 784). It proposed defining the legally protected beginning of human life as the moment of conception, ${ }^{4}$ introducing into the Criminal Code the legal definition of a

\footnotetext{
${ }^{3}$ On 1 March 1989, at the initiative of a group of deputies from the Polish Catholic and Social Union, a bill on the legal protection of a conceived child was submitted to the Sejm, prepared in cooperation with the Polish Episcopate's family experts. This draft included an absolute ban on abortions and the proposal of a punishment for abortions, which caused a wave of protests, discussions, publications and collective speeches to the Sejm, but it did not go to its plenary session.

${ }^{4}$ Article 1 of draft: "Every human being has an inherent right to life from the moment of conception, i.e. from the moment when female and male reproductive cells join. The life and health of a child from the moment of conception are subject to legal protection". (From here on, all quotes are translated by the authors).
} 
conceived child, ${ }^{5}$ as well as changing the principles of imposing abortion-related penalties. Most importantly, the draft also provided for imposing penalties on pregnant women who deliberately terminated their pregnancies. The draft was rejected by parliament on 6 October 2016, following a series of social protests of unprecedented force and scale in Poland. These protests are discussed in more detail further on. On 30 November 2017, right-wing circles submitted another legislative project named Stop Abortions (voter bill initiative, Sejm paper № 2146), only slightly less radical as it delegalised abortion in only one of the allowed cases - for eugenic reasons.

On 4 August 2016, the Legislative Initiative Committee Let's Save Women submitted a bill on the rights of women and conscious parenting (Popular bill initiative, Sejm paper № 830), recognising the right to freely terminate pregnancy until the end of the $12^{\text {th }}$ week, and limiting the right to abortion after the $12^{\text {th }}$ week of pregnancy to three cases. The bill was rejected twice. ${ }^{6}$

Summing up, despite numerous attempts to change the law and the ensuing debate, the abortion compromise form 1997 has never been changed. Instead, it is the interpretation of the defence of reproductive rights and life enshrined in the law that has changed in an ambivalent and functional way for the consolidation of political alliances/strategies at national and transnational levels, especially in the post-Soviet period.

\section{The genealogy of neo-conservative attacks on abortion rights in Italy}

In Italy, the influence of the Catholic Church in matters of abortion has been present in the national law since the approval of the Criminal Code in 1931, during the fascist period. The code criminalised abortions, providing for up to four years imprisonment for a woman who had an abortion and anyone who helped her (Calloni 2001). Articles 545-552 of the Criminal Code, the ones criminalising abortion, were questioned in the early 1970s with the emergence of feminist movements, in the context of radical social changes like the introduction of divorce in 1970 and the reform of family law in 1975. Thanks to the movement's push and the engagement of several progressive MPs not connected with the church, a new law was approved in 1978 decriminalising abortions performed by the National Health Service.

The feminist struggle for access to safe abortions was particularly significant, because it revealed the widespread awareness of how control over reproduction was a device of women's oppression within the traditional family institution (Pitch 1998). Feminists framed the topic as the right to health and women's psycho-physical integrity by recognising the centrality of women as political subjects (Calloni 2001). The public opinion consensus on women's health rights was claimed by mass mobilisation and reaffirmed by the establishment of family consulting centres (Law 405/1975 Istituzione

\footnotetext{
${ }^{5}$ Article 24 of draft: "A conceived child is a human being in the prenatal stage of development, from the joining of the female and male reproductive cells".

${ }^{6}$ At the time of writing, on 15 April 2020, another attempt to ban abortions took place, taking advantage of the COVID-19 crisis which prevents the possibility of a normal, full and available public debate. With a view to gaining political benefits in connection with the upcoming presidential election, the act was addressed to the Social Policy and Family Policy Committee and the Health Committee (it means that the draft bill is in the "parliament freezer"). Despite the difficulties, the Nationwide Women's Strike and the Federation for Women and Family Planning launched online and offline campaigns (see, for example, https://www.facebook.com/events/220757995692975/).
} 
dei consultori familiari/Establishment of feminist clinics): self-managed feminist clinics institutionalised during the 1970s, in which family planning and contraceptive methods became tasks of the National Health Service (Calloni 2001, Bracke 2017).

Italian feminist movements succeeded in placing abortion as a prominent issue in the public debate and made it a priority in the political agenda, also at parliamentarian level. The "use of law" was only one of the political strategies of the feminist groups, and not the most popular one in the movement (Calloni 2001, Hanafin 2007, Bracke 2017). Certain collectives (Libreria delle donne di Milano 1986) rejected the use of the State's law as a further form of control on women's bodies by the State (Pitch 1998, Peroni 2015), preferring to organise forms in the self-managed model of clinics run by women for women outside the domain of male medical power (Hanafin 2007).

Law 194 was approved in 1978, after seven years of complex and intense public and parliamentary debate (Calloni 2001). Contrary to the feminist movements' requests, this law removed abortion from the Criminal Code, but introduced several conditions for performing it under the exclusive and total control of medical experts: 1) time constraints - within the first 90 days of pregnancy; 2) the provision of a medical evaluation on the social, economic, psychological and physic circumstances of the woman intending to abort; 3 ) the possibility to abort the pregnancy only in public hospitals or authorised private socio-medical facilities, and 4) in Article 9, the law gave the healthcare personnel the ability to refuse to perform medical abortion procedures on religious and moral grounds - known as a "conscientious objection" (Ozzano and Giorgi 2015). This last provision was a compromise with the more conservative factions of the Catholic Church and the pro-life movements, which pursued - and continue to do so - a twofold strategy of hindering the full application of the law by exploiting its constraints and by spreading an anti-abortion moral discourse by questioning the legitimacy of a woman's choice over her body, although not all Catholics opposed the law for the decriminalisation (Gozzini 1978 in Calloni 2001). These constraints to abortion have two intertwined roots: the social and political influence of the Catholic Church, and the patriarchal and sexist culture of political parties - and of society in general. ${ }^{7}$

After the law was approved in 1978, there was an abrogative referendum ${ }^{8}$ promoted by conservatives and the Christian Democracy Party in 1981. Even though the referendum failed, it marked a threefold historical milestone: it introduced the legal protection of human life from conception; it broke the alliance between the feminist movements and the political left wing; and it dissolved the feminist movement from the piazze (Valentini

\footnotetext{
${ }^{7}$ Following the Catholic Church doctrine, the first Italian Criminal Code (1889) considered abortion to be homicide, since the life or soul of the foetus must be protected from its conception. In 1930, the Fascist regime introduced a new code, named Codice Rocco, which defined abortion as a crime "against the interest that the nation has, as an ethnic unit, to defend the continuity and integrity of the stock" (Hanafin 2007, p. 28). The Catholic morality and the major interest of the (patriarchal/masculine) nation were the main rhetoric argumentations for the ban on abortions. Moreover, control over the generative choice was also reaffirmed through the pro-natalist policies (Palini 1977 in Calloni 2001) and the exaltation of "motherhood". As we will illustrate below, these arguments have remained present in the Italian public debate about reproductive rights and women's freedom of choice over their own bodies to this day.

${ }^{8}$ The Radical party and part of the feminist movement also promoted a referendum for the abrogation of the law for the opposite reason - because there were too many limits on a woman's right to interrupt her pregnancy.
} 
1997). During the decades that followed, feminist groups continued their theoretical, practical and political elaborations, but within more restricted groups, almost disappearing from the mainstream public debate (Hanafin 2007).

After the failure of the 1981 referendum, the conservative and pro-life movements, together with the Catholic Church, openly and constantly reaffirmed the need to protect human life from conception, since it is an inviolable value - e.g. Evangelium Vitae, John Paul II 1995.

Starting from the late nineties, parliamentary and public debates on Assisted Reproductive Technologies (ART) and Embryonic Stem Cell Research (ESCR), promoted by conservative forces, tried again to question the right to an abortion (Ozzano and Giorgi 2015), through the affirmation of the prevailing interest of the embryo over that of the woman, and the sacredness of the natural process of human reproduction versus scientific research (Hanafin 2007). In the early years of this century, the discussion on technologies applied to the beginning of life continued to be central in parliament and in public debate - Law 40/2004, the experimentation of RU486 (medicine for chemical abortion) - until the foundation of a new political party named Aborto? No Grazie! ${ }^{9}$ (Abortion? No, thank you) in 2007 by the journalist and politician Giuliano Ferrara (Ozzano and Giorgi 2015).

However, although Law 194 is still in force, the conscientious objection is the means through which it has been gradually emptied of its real effectiveness. As forecast by the feminists in the seventies, the most dangerous consequence of the provision of consciousness objection set out in Article 9 of Law 194 is the increasing number of objectors in the Italian public health system. This now makes it almost impossible in some regions to obtain an interruption of pregnancy. Currently the rate of objectors is at $68.4 \%,{ }^{10}$ while in hospitals offering abortion services, the proportion is $64.5 \%$. The number of objectors varies around the country, from just $17.6 \%$ of public health officials in the Valle D'Aosta Region to $96.4 \%$ of the Molise Region, with these two extremes representing the non-homogeneous distribution of abortion services among the Italian regions (Ministero della Salute 2018). According to Autorino and others (2018), this gap inevitably leads to insufficient availability of abortion services in parts of the country, resulting in intra- and inter-national abortion-related migration. These conditions create a further discrimination against women who cannot afford the economic cost of travel, and who in some cases are forced to either carry unwanted pregnancies to term or resort to illegal abortion (Figà-Talamanca et al. 1986).

These examples illustrate the resistances to recognising women's juridical and political subjectivity and the persistent power of the (male) State over their own bodies. Nowadays, reproduction is still the political site of conflict concerning women's citizenship, rights, freedoms and self-determination. ${ }^{11}$ In this area, self-management

\footnotetext{
9 The Aborto? No Grazie party had $0.3 \%$ of support in the 2008 political election. Beyond the awful voting results, it was relevant due to its important voice in the public debate.

${ }^{10}$ The longitudinal data show that the average rate of gynaecologist objectors increased from $58.7 \%$ in 2005 to $70.9 \%$ in 2016, and was $68.4 \%$ in 2017 - last available data (Ministero della Salute 2017).

${ }^{11}$ During the COVID-19 sanitarian crisis, at the time of writing, we are observing an increase of difficulties to access to abortion rights due to the overload of hospitals, which has led feminist group Obiezione Respinta to advocate for a guarantee of access to a pharmacological abortion (Obiezione Respinta 2017a).
} 
and support between women remain the main practices of feminist and women's movements, both in online and offline mobilisation.

\section{The backlash in Poland and Italy}

\subsection{Repertoires of action}

Notwithstanding the different genealogies and the different access to abortion rights, both countries are seeing pro-life organisations conducting their strategies with recurrent repertoires of action and targeting different audiences, not only concerning abortion, but also about the rights of sexual minorities. This strategy, which started in the first decade of 2000, has been grounded on three main dichotomies related to each other: LGBTQI reproductive rights/defence of the traditional family; sexual education at school/exclusivity of parents' pedagogical role in the field of children's sexuality; abortion rights/motherhood as women's moral destiny in society. Indeed, the antigender, right-wing and neo-conservative backlash converges in both countries in the same political strategy: censorship of sexual education, attacks against sexual and reproductive citizenship rights and defence of the traditional family based on the imagery of women as mothers of the nation. Considerable relevance is given to online and offline communication through campaigns whose common discursive strategies are the manipulation of feminist claims against femicide - i.e. the campaign "Hospitals without abortions" ("Hospitals without physicians who practice abortions": https://stronazycia.pl/stop-aborcji/szpitale-bez-aborterow/) in Poland, and the campaign of Citizengo.com ${ }^{12}$ in Italy; the elimination of neutral terms through the introduction of "proper" sounding synonyms, and redefining terminology with the aim of morally criminalising abortions. Moreover, pro-life and anti-gender groups are transnationally interconnected through the use of social media and the internet, which are sites of intense activities of recruiting and mobilising.

The common repertoires of action include manifestations, marches, conferences exhibitions and picketing in front of hospitals. Being active on the cultural dimension, participating in public debates and occupying public spaces is important, as these are the means used to affect the political level in order to achieve legislation that is more coherent with their understanding of morality, society and natural family.

\subsection{Defending the "natural family"}

One of the main tactics is the rallying of pro-life organisations for the defence of the "natural family". In Poland, Marches for Life and Family (Marsze dla Życia i Rodziny) are organised in order to present public testimony about the value of human life from the moment of conception, and of family based on the "natural" relationship between man and woman and a prohibition of birth control methods. The vibe of those marches is quite positive, celebratory and affirmative. Each year they are organised under a different slogan, but always express an expectation of such social and legal changes that

\footnotetext{
${ }^{12}$ As stated in their website, CitizenGO is a community of active citizens - funded in 2013 - who work together, using online petitions and action alerts as a resource, to defend and promote life, the family, and liberty. They work to ensure that those in power respect human dignity and individuals' rights. CitizenGO is present all over the world, offers campaigns in 12 languages and aims to influence institutions, governments and organisations in 50 different countries.
} 
will provide the fullest protection for human life and family rights. In Poland, the first march took place in 2006 in Warsaw. Through the span of 13 years, marches have been organised by more than 150 towns and cities, and this number is still growing. In a perfect populist frame, they use nationalist imagery that accuses the presence of foreign influences in the understanding of what family and the protection of life are. As mentioned, example slogans of the march refer not only to the defence of life from the conception, but denouncing the attack on the heterosexual family - To protect Polish families from the LGBTQI dictatorship and Let Polish families be strong - as well as the desire to destroy the natural order through the indoctrination of the younger generation - Sex education is depravation. ${ }^{13}$

In Italy, this strategy has been undertaken by the Family Day - Let's Defend Our Children! organisation, which reached significant relevance in the Italian public arena during the second decade of this century (Garbagnoli and Prearo 2017). This neoconservative, right-wing, Catholic culture landmark includes a galaxy of interconnected historical ${ }^{14}$ and recent ${ }^{15}$ movements and organisations firmly aligned with Catholic institutions, political parties and international donors. In that period, there were three legislative proposals regarding the recognition of LGBTQI rights which led to social and political conflict. ${ }^{16}$ The neo-conservative Catholic movements countered all three proposals, invoking the defence of the "natural family" and the protection of children from the attack of "Gender Ideology" corrupting the heterosexual social order. In this way, the defence of "our children" from Gender Ideology has turned into the defence of the traditional family as a gendered paradigm in which women are destined to embrace motherhood. Consequently, the discourse against abortions no longer refers to the defence of life from conception, but has broadened to become the defence of the traditional family.

\subsection{Deturning anti-capitalist and feminist claims}

This strategy has also been applied by the organisation of the World Congress of Families in the city of Verona, Italy, and the introduction of "pro-life motions" in several city councils, again starting in Verona. Pro-life motions have been presented in several city councils since October 2018, claiming the full application of Law 194/1978 relating to maternity protection, in particular claiming more funds for pro-life centres. In this context, it is perhaps little wonder that Verona was announced as the next city hosting the World Family Congress, an international meeting of neo-conservative and integralist parties. The World Congress of Families (WCF) is a "major international

13 This is the slogan of the march that took place on 9 June 2019 (https://marsz.org; https://www.radiomaryja.pl/informacje/seksedukacja-to-deprawacja-marsz-dla-zycia-i-rodziny-2019/).

${ }^{14}$ Il Movimento per la vita (MPV) is an association founded in 1980 to promote the value of human life from conception until natural death. It can be considered an example of a conservative movement that has adapted its strategy over time. In addition, as stated on its website, the activities of MPV include several sectors: education, culture, research and information, and legislation, in addition to social services.

15 The members of the organising committee of Defending Our Children belong to five main organisations: Non Si Tocca la Famiglia (Hands off the Family), La Manif pour Tous (Demo for all), Scienza e Vita (Science and Life), Giuristi per la Vita (Lawyers for Life) and Provita (Pro-Life).

16 The Cirinnà Bill (2013), on the recognition of same-sex couples; the Fedeli Bill (2014) on the integration of educational programmes on gender identities in schools; and the Scalfarotto Bill (2013) on making homophobia a criminal offence. 
public event that seeks to unite and equip leaders, organisations, and families to affirm, celebrate, and defend the natural family as the only fundamental and sustainable unit of society." 17 Since 1997, the Christian right (Buss and Herman 2003) International Organization for the Family (IOF), based in Washington DC, is the major promoter of this event, which has been held in several cities around the world promoting the antigender cause and pro-family discourse. The XIII edition of the WCF, hosted in Verona, pursued a three-pronged strategy: to engage political representatives and influence the political agenda, to be recognised by Christian/Catholic institutions as a promoter of their messages, and to increase their rooting at a local level and boost their cause among the "people". The government representatives ${ }^{18}$ who attended the Conference gave several interviews, press releases and political meetings declaring their intention to limit access to legal abortions and to reduce public funding for it, thereby reaffirming the centrality of heterosexual family in Italian society.

The WCF's Verona Declaration, issued on March 2019, not only ambiguously mixes references from religious doctrine and social sciences (Buss and Herman 2003, Bellé et al. 2018), but also borrows its keywords from anti-capitalist and feminist claims: it defines the role of the family as a fundamental "body" "to fight against the current cultural and economic crisis" and to prevent our society from becoming "a mass of obedient, servile consumers who would not recognise their roots and traditions, and as such would be more easily manipulated by those powers who would exploit them for profit." Moreover, it claims "appropriate remuneration for housework where the spouse's salary is not sufficient for a free and decent existence and when women dedicate themselves exclusively to children and the family." This recalls the historical feminist claim for a domestic salary (Dalla Costa 1988), but actually consists in a proposal of a "maternity income".

\subsection{The backlash against feminism}

Last, but not least, the core repertoire of pro-life lobbies is campaigning against feminism itself. For example, in February 2018, a Polish online campaign was launched: "I'm a woman. \#NotFeminist". ${ }^{19}$ On the Go Against The Flow portal, two videos were broadcast in which several ladies and their husbands, dressed in patriotic clothing, tore up cards showing a symbol of the women's black protest and explained why this is not feminist. ${ }^{20}$ In addition, former PiS Prime Minister Beata Szydło declared that she is not a feminist. What is interesting, in 2008 Elżbieta Radziszewska (from the Civic Platform party), a former plenipotentiary for equal status for women and men, also said: "I am not a feminist." It seems that in right wing and pro-life circles, saying that "I'm not a feminist" means - I'm a wise, reasonable woman and I know my natural role I must

\footnotetext{
17 Verona World Congress of Families (WCF) website: https://wcfverona.org/en/about-the-congress/

${ }_{18}$ Minister of Interior, Matteo Salvini and Minister of Family and Disability, Lorenzo Fontana.

19 See Part I of the campaign video: https://www.youtube.com/watch?v=zRe1fEk5TDk and Part II: https://www.youtube.com/watch?v=dXSRkXeAwck

${ }^{20}$ As they say, they are not feminists because: "being a feminist is stupid"; "feel free as a women"; "feminism is not female"; they "like asking their husband to help them with something"; they "like it when a man shows them respect"; they "can't imagine themselves giving security to their husband"; and that "feminism strips a woman of such attributes as grace, beauty and sensitivity."
} 
play. As one of the women in the campaign says, "Feminism goes against reason, and I value reason very much."

In Italy, the anti-gender movement tried to deprive and deturn some of the historical keywords of the feminist social movements in order to avoid the accusation of being misogynist and anti-feminist. For example, the Family Day leaders tried instrumentally to ally with the feminists of difference concerning opposition to "surrogate motherhood", by referring to the defence of female power to generate, transforming this concept into a heteronormative dictate to reproduce (Bellè et al. 2018). More recently, in 2018, CitizenGO, when promoting the participation to the Marcia per la vita (March for Life), put up a poster in front of a hospital in Rome declaring that "abortion is the top cause of femicide in the world", overturning the feminist discourse against genderbased violence within a hetero couple or marriage, and the patriarchal culture of our society made by Non Una Di Meno. This can be read as part of the Vatican's "new feminism", a strategy used to legitimate the essentialisation of women within the heterosexual family (Garbagnoli 2017).

These attempts reveal quite clearly what is at stake in the "war on Gender Ideology": the fight against the feminist political movement struggling for the self-determination of women and LGBTQI people. The populist claim of going "against the flow", associating the new wave of feminism with a mainstream elitist lobby, shows that the counter-position "us-them" of populist discourse is definitely designed on the identity line feminist/non-feminist. Therefore, we could argue that the conflict for citizenship and the redefinition of identity values in general is now played on this field.

\section{The feminist movements in Poland and Italy}

\subsection{Resisting the backlash and striking patriarchy}

In August 2016, a wide women's movement mobilised against the neo-conservative attacks against the right to an abortion in Poland, converging in a national strike called Black Protest (Korolczuk 2016, Hall 2019). After a few months, in October 2016, Argentinian women mobilised against a series of heinous femicides culminating in the murder of Lucia Pérez, a 16-year-old girl victim of group rape and torture, giving birth to the national movement Ni Una Menos. The re-emergence of these two historical key topics of feminist movements at an international level fostered the birth of what came to be known as the fourth wave of feminism, especially in Europe and America. This alliance is nourished by the transnational alliance of feminist struggles and LGBTQI claims against gender-based violence, understood as an intrinsic element of the plot of heteropatriarchy, neoliberalism and populism characterising this new phase of capitalist accumulation.

It is often argued that feminist movements in Poland did not exist until recently (Graff 2014, Salvatori 2018), while in Italy the history of feminist movements is well known and recognised worldwide. As Salvatori points out, this analytical divide must be overcome using a different perspective, by taking into consideration the strong but often overlooked connections existing between revolutionary women in West and East Europe after the Second World War (Bonfiglioli 2011, Salvatori 2018). Moreover, the contemporary transnational alliance for reproductive rights can be understood as the 
convergence of different temporalities and processes of women's movements. While Graff (2003), when referring to the Polish movement, criticises the framing of feminism in waves and pushes for a more specific and contextualised analytical framework, we would propose a different understanding of feminist waves as movements that rise and flow without ever disappearing completely, but maintaining connections and relationships that emerge in specific historical moments, such as what is going on currently (Salvatori 2018).

This has been possible due certain common characteristics in terms of political framing, practices and repertoires of women's mobilisation worldwide. According to Munro (2013), the fourth wave of feminism can be defined as "hashtag activism", based on the massive use of social media, creating networks of mutual support, raising awareness of women's needs along with social and legal rights.

Indeed, the first launch of national and then global mobilisation by Ni Una Menos and the Black protest, and the process of feminist subjectivation in a transnational context have been possible through the use of social media (Pavan and Mainardi 2018), in what Bennett and Segerberg (2012) and Korolczuk (2016) referred to as "connective action". As Salvatori (2018) argued, connective action can be interpreted as a translation via social media of the historical feminist practice of sharing subjective experiences in circles of self-consciousness, overcoming the traditional separation of private/public, which opens a new social space for subjectivation and politicisation, as happened in the \#MeToo campaign (Fotopoulou 2016, Mason-Deese 2018, Peroni 2018).

In the frame of Hashtag feminism, the connective action gave new space and shape to the feminist repertoires of political action. On the one hand, the feminist use of the internet helped organise transnational mobilisation based on common claims and campaigns. Indeed, when it comes to the repertoires of political action, all these struggles converged in the practice of social and feminist strikes, overcoming the classic forms of demonstrations and street protests of social movements. In particular, the opposition to the Polish attempted ban on abortion in October 2016 mobilised thousands of women in a national women's strike, claiming the recognition of the reproductive work of women, and therefore of their whole lives. Women's strikes immediately became the main form of feminist mobilisation, and on 8 March 2017, an international women's strike was launched by the Argentinian movement Ni Una Menos and the Polish Black Friday protest (Paro international). On the other hand, the historical practice of mutualism and self-help about reproductive rights and sexual health have become a common practice, connecting women and girls worldwide through blogs and social networks, used as tools of communication and raising consciousness capable of overcoming national and social boundaries.

\subsection{The women's strike for self-determination}

The international women's strike was launched with the Black Protest in Poland - a series of nationwide, large-scale protests organised between September 2016 and 2018, against the proposal to further restrict women's rights to an abortion. The protest was carried out on an unprecedented scale in a coordinated national strike - the Black Monday - on 3 October 2016, in response to the proposal to introduce a total ban on abortion (the draft Abortion Stop Act). 
The idea for the mobilisation was born spontaneously on the internet; ${ }^{21}$ assemblies were organised in 147 Polish towns and cities under the slogan Black Monday/Nationwide Women's Strike (http://strajkkobiet.eu/czarny-poniedzialek/). The number of people actively participating in the protest was estimated at between 98,000 and 200,000; the same number of people did not go to work that day, and another half a million went to work in black clothes, as a gesture of solidarity with the protesters.

This is considered the real birth of feminism in Poland - as Ewa Majewska described it, "[n]ot an exclusive movement of middle-class women from urban elites, but a nationwide, and then also an international, women's mobilisation in several countries, for the sake of our rights to an abortion in Poland"(Majewska 2016). Women protested on their own behalf, but also for their daughters, or simply for all women. Motherhood and the right to an autonomous decision became an impulse to enter the public space. A series of Black Protests integrated people from different backgrounds, not only those with a "feminist history", but everyone - from the political right and left and spanning all social classes.

On the basis of the Black Monday campaign, the National Women's Strike ${ }^{22}$ was formed - an informal, non-partisan initiative of women belonging to various women's organisations, as well as (mainly) those that were non-affiliated. Then groups such as Dziewuchy Dziewuchom, Sexedpl Foundation and Abortion Dream Team were formed on the wave of the National Women's Strike. Feminist and civic organisations (including: Manifa, Feminoteka, Foundation for Women's Rights Centre, MaMa Foundation and Women's Space Foundation) arose in opposition to restrictive changes in the law.

The phenomenon of 3 October 2016, however, was primarily connected with the fact that on that day a significant part of the society, regardless of the support for a particular political option, took to the streets to express its opposition. It was the largest solidarity protest in the history of Poland dedicated exclusively to the issue of women.

The National Strike of Women later organised other events constituting reactions to the attempts to tighten the abortion laws, including the International Women's Strike mentioned above. There was the Black Wednesday protest against Parliament's rejection of the popular law proposal Let's Save Women 2017 for the liberalisation of abortion rights, and against the draft law of the \#StopAbortion Committee. The National strike manifesto claims for: full reproductive rights; a superstition-free state, with reliable sex education; liquidation of the Conscience Clause; the implementation and application of the Istanbul Anti-Violence Convention; improving the economic situation of women; and the understanding that human rights are for everyone, including women, LGBTQI people, people with disabilities, national, ethnic and religious

\footnotetext{
${ }^{21}$ Some inspiration for the action was a Facebook post by the famous Polish actress Krystyna Janda, on 24 September 2016, on the 41st anniversary of the Icelandic women's strike in 1975 (see http://strajkkobiet.eu/2018/10/01/herstoria-strajku-kobiet/ and https://obieg.u-jazdowski.pl/numery/ polskosc/we-will-not-fold-we-will-not-fold-our-umbrellas-pl).

${ }^{22}$ As they write on the website: "We are a grassroots, independent social movement of pissed off women and intelligent men supporting us. We protest and act for women's rights, democracy, Poland for all, mobilising in over 150 towns and cities in Poland - 90\% of them towns with less than 50,000 inhabitants, which is our greatest strength and pride" (Strajk Kobiet 2017).
} 
minorities, elderly and people with economic difficulties. The women's protests were focused on self-determination, recognition and rights, and their statements were: "I think, I feel, I decide", "Women's rights are human rights", "Your law is killing us", "My body, my choice", "Women's blood on the hands of church" and "Women are not incubators". As Korolczuk $(2016,92)$ points out, the "black protests" were a "revolutionary moment when fear and anger were transformed into feelings of solidarity and empowerment, a moment of personal and collective transformation."

As Gunnarsson-Payne aptly reports, the success of the Black Protests was determined by three factors:

1) the actual ability to mobilise broad sections of society, resulting in the politicisation of a large number of people who had previously not identified with either the movement or politics; 2) effective mobilisation strategies centred around one key problem (abortion) that has been successfully combined with other political issues as part of a larger opposition campaign involving numerous leftist and feminist demands; 3) very fast mobilisation at a supranational level, which led to the formation of a global, solidary, united movement of feminist struggle. (Gunnarson-Payne 2019, 159)

In addition, under the influence of protests, women in Poland began to understand that the issue of abortion and attempts to violate the "abortion compromise" potentially concerns them all - this matter is not an abstract dispute about the beginning of "life", but a real dispute in which the price is the health and dignity women in Poland. It seems that a direct effect of the strike was the departure of the authorities from offensive, aggressive rhetoric in favour of a softer approach, with a "human face". Prime Minister Beata Szydło announced that Polish women who go through a "difficult pregnancy" (i.e. when the foetus is terminally ill or has genetic defects) will be able to receive a onetime payment of approximately EUR 1,000, a flat-rate cash payment for giving birth to a child that will probably die soon after delivery. It is likely that the bill was the government's "response" to the ongoing abortion debate and was intended as an attempt to "settle the dispute" (Komisja Polityki Społecznej i Rodziny, 2016).

The feminist strike is also one of the main issues of the Italian movement Non Una Di Meno (Not One Less - NUDM), which has dedicated several national meetings to defining its framing and practices. For feminist activists, striking is a political and social process of abstention and the rejection of gender-based violence, neo-fundamentalist attacks to women's and LGBTQI self-determination and the exploitation of traditional gender roles on the labour market and in society as a whole.

The movement NUDM developed a new discourse and practice of rights by creating a new normativity that overcomes the historical feminist distinction between "from below" and "from above the law" (Cigarini 1994), as Italian historical feminism has put it; recomposing these different historical approaches in a new way. The articulation of NUDM's analysis closely resembles and has the same genealogy as the feminist approaches of the 1970s, with the transfeminist paths of the last 10 years, on the one hand critiquing the production of state law as a device exclusively based on women's criminalisation and victimisation, and on the other claiming autonomy in all spheres of life through new social norms and horizontal organisational practices alternative to institutional ones. This has been possible as different generations of women are 
participating in national and local meetings, creating relationships based on recognition and exchange in political action.

One of the most extraordinary products of this intense intergenerational relationship is drafting The Feminist Plan Against Male Violence on Women and Gender Violence, published on the occasion of the demonstration of 25 November 2017, after one year of intense work by hundreds of activists within the eight round tables in which the national meetings were split since the beginning of the movement in 2016. The Plan was the feminist response to the government's Extraordinary Plan Against Gender-Based Violence, of which it criticised the ideological structure by openly contesting its security, emergency and repressive approach (recalling the historical critique to the state's law as a device for the criminalisation and victimisation of women's subjectivity). The Plan has become a real tool of a new autonomous normativity and an instrument of global and intersectional analysis of cultural, social, educational and operational proposal against gender-based violence in all its forms. The Plan constituted the starting point for the mobilisation towards the strike of 8 March 2017. For this event, the movement issued 8 points for $8 \mathrm{March}^{23}$ translating each chapter of the Plan into clear claims:

We strike because we demand free and safe abortion, and the abrogation of conscientious objection; we strike against obstetric violence; we strike for free and full access to the RU486 pill, which must be administered in day hospital until the $63^{\text {rd }}$ day; ${ }^{24}$ we strike against abortion stigma and we refuse sanctions against women who have abortions outside of legal procedures due to high rates of conscientious objection; and we strike so that everyone can exercise their right to self-determination. (Non Una Di Meno 2017a)

In the Feminist Plan, a feminist strike is claimed as a form of protest against the gendered violence of medicalisation and medical control over women's bodies, and of the "re-appropriation and re-signification" (Non Una Di Meno 2017b, p. 31) of traditional union strikes in order to reject and "subvert the sexual hierarchies, the gender norms and the imposed social roles - in this sense, we have also defined it as a strike of and by genders".

Regarding the right to abortion and the neo-conservative construction of motherhood as the only and natural destiny for women, striking means opposing the whole cultural and social structures underlying women's heterosexual oppression, while at the same time taking a transfeminist position on relationships, parenting, love and sex based on desire and pleasure.

\subsection{De-blaming abortion: Women's mutualism for self-determination}

In the Polish public debate initiated by the Black Monday protest, new threads appeared that had not previously been discussed - known as "abortion coming out" (voices of those women who had undergone an abortion in the past). Undergoing an abortion in Poland is treated as a kind of stigma, and confessing to carrying out this procedure is treated as "confessing to murder". Few artists spoke about abortions openly before 2016 breakthrough. One of the main actions in this field was the campaign "Abortion is OK"

\footnotetext{
23 "8 punti per Lotto marzo": "Lotto" is a play on word meaning both "The 8th" (L'8) and "I Fight" (Lotto). ${ }^{24}$ Pharmacological abortion is between 92 and 99 per cent effective. In Italy, it can be practiced until the $49^{\text {th }}$ day of pregnancy.
} 
(http://aborcyjnydreamteam.pl), starting with the cover of the liberal magazine Wysokie Obcasy (15 February 2018) showing a picture of three young women in T-shirts with the words Abortion is OK.

They also co-created the initiative "Abortion Dream Team On Tour". As they describe this on Facebook, the initiative aimed at talking "about abortion normally - without taboos, without drama, without distortions and without fear." (from the Abortion Dream Team Facebook page: https://www.facebook.com/pg/aborcyinydreamteam Labout/?ref=page internal). ADT announces on its website where it is possible to carry out an illegal abortion. They also publish information about the detailed course of a pharmacological abortion along with scientific research about the influence of abortion and testimony from women who have experienced it. ADT also organises information meetings on pharmacological abortions and abortion storytelling. Before the "Abortion is OK" campaign was launched, ADT and Women on the Web initiated a billboard campaign in six Polish cities. The posters said: "One of your friends has had an abortion. You are not alone." It was a response to "bloody, lying and shocking anti-choice billboards." According to the organisers of the action, such billboards stigmatised not only women who decide to have an abortion, but also "distort facts, manipulate and shake". The campaign was intended to emphasise the universality of the abortion experience and be a signal of solidarity for all women who have decided to have an abortion. This form of communication was immediately accused of trivialising the problem, which in the social and personal (emotional, moral) sense is an abortion. ${ }^{25}$ It was an attempt to talk about the termination of pregnancy as a common and even normal event in female reproductive life.

One week after the campaign "Abortion is OK" started (Friday, 16 February), the Facebook profile of Wysokie Obcasy magazine published a post about the slogan Abortion is $O K$ from the editorial staff. They explained that: "It's a slogan that says abortion is fine, because it gives you the opportunity to choose. It appeals to women who have decided to have an abortion and do not feel a mental burden or trauma, because it would be traumatic for them to give birth to a child at this point in their life" (https://www.press.pl/tresc/52186, wysokie-obcasy -mocno-krytykowane-za-hasloaborcja-jest-ok_). Protests and petitions from the right-wing caused the resigning of Wysokie Obcasy editor-in-chief and the author of the article. ${ }^{26}$

On 30 September 2018, a march took place in Warsaw as part of the celebration of the World Day of Safe Abortions. Polish pro-choice activists demonstrated the demand for a legal, safe, free and fully available termination of pregnancy. The demonstration, under the slogan Abortion means life, attracted about one and a half thousand people. For the first time, they marched not only against the law, but in favour of women's right to a fully legal, safe, completely available abortion. The organisers of the march were the Abortive Dream Team. On the wave of the success of this campaign, feminist circles began to talk about abortion as a normal medical procedure that should be publicly

\footnotetext{
${ }^{25}$ See, for example, the critics by tvp.info: https://www.tvp.info/36023855/aborcja-jest-ok-okladka-i-artykuldodatku-gw-reklamuje-zabijanie-dzieci

26 "Abortion is not OK. Abortion is death!" - https://www.maszwplyw.pl/aborcja-nie-jest-ok--aborcja-tosmierc-, $80, \mathrm{k} \cdot \mathrm{html}$
} 
available, as well as to encourage opening up to "testimony" about abortions made on request (abortion storytelling).

The need to absolve abortion of blame and to create platforms of mutual support for women willing to interrupt their pregnancy was also one of the main focuses of the Feminist Plan issued by Non Una Di Meno in Italy. In Chapter 4 of the plan, the movement describes the reproductive rights as part of a woman's right to "[p]sychological, physical, sexual and social wellbeing and as an expression of freedom", connecting sexual health to desire and self-determination, and overcoming the mainstream moralistic approach to reproduction and abortion. One of the main concerns of NUDM is the serious increase in medical conscientious objection, as this affects the effective enjoyment of the right to interrupt the pregnancy enshrined in the law. Beyond the mere defence of the law, NUDM claims \#moltopiudi194 ("much more than 194", from the number of the law on the voluntary interruption of pregnancy), namely: the total decriminalisation of abortions, including backstreet abortions; the total exclusion of conscientious objectors from public services and hospitals; more sexual and gender education in schools; the re-politicisation of the consultori (family consulting centres born as feminist clinics during the seventies and institutionalised under Law $405 / 1975)$; the opening of a new generation of transfeminist and queer clinics, described as

spaces of experimentation, self-inquiry, mutualism and redefinition of welfare, in order to rethink and reconstruct processes of circularity between new experiences of self-management and forms of re-appropriation of services; places to elaborate strategies of collective intervention with respect to self-determination of all, male and gender-based violence, health and sexual pleasure. (Non Una Di Meno 2017b, p. 26)

The assemblage of claims contained in the Feminist Plan and in the eight points highlights the main political frames drawn up by NUDM to claim reproductive selfdetermination, considering the right to an abortion as part of a more general claim for sexual and reproductive health, including sex education and self-determination. In this sense, the consciousness objection is described as a form of patriarchal violence against women's freedom. Therefore, the movement aims to stop the moralistic blaming of abortions and practicing forms of mutualism and self-help beyond state's control and medicalisation.

These claims have been translated in the launch of obiezionerespinta.info, a blog for mapping and collecting information via social media about the hospitals and pharmacies that practice conscientious objections, in a form of mutual support about safe and independent medical support. The platform was launched during the NUDM's general assembly held in Bologna in February 2017.

The aim of the project, as stated by the activists, is to enhance feminist solidarity, mutualism and self-help against the medicalisation and the control of motherhood and the reproductive capability of women. Beyond reporting where objections are practiced, the platform produces and spreads information concerning contraception, sexuality and 
abortion, claiming the centrality of feminist knowledge where the object of knowledge is a woman's body. ${ }^{27}$

The website is interactive and is linked to a Facebook page with 15,000 followers. In addition to information on conscientious objectors, the page posted many articles and international campaigns concerning self-determination and sexual health.

"Obiezione respinta" is also the title of a campaign launched by NUDM for the $40^{\text {th }}$ anniversary of the approval of Law 194. On this occasion, NUDM launched a call for a week of national mobilisation (Non Una Di Meno 2018). The call is for local actions, parades and flash mobs in front of hospitals and pharmacies where objection is practiced, but also for demonstrating in favour of the right to have an abortion and selfdetermination beyond the mere defence of the law itself. Moreover, NUDM declared the intrinsically transnational nature of this mobilisation, contextualising it within the global populist backlash for dismantling women's rights and freedom, but at the same time recalling the force and solidarity of women worldwide in the appearance of a new global transfeminist and intersectional sisterhood.

\section{Conclusion}

In this paper, we analysed comparatively the counter-position of anti-gender and feminist mobilisations that have occurred in Italy and Poland in recent years within the frame of the global populist and neo-conservative backlash against women's and LGBTQI sexual and reproductive rights. The anti-gender strategies of these two countries are part of a transnational strategy that uses the same rhetorical tools by adapting them to the national contexts and political traditions: Western and post-Soviet ones. On one side, it is associated with Orwell's "single thought", and on the other to a form of new Marxism, an infiltration of "EuroAmerican depravation" (Datta 2018). These strategies lead to fuel the moral panic against the cultural colonisation of foreign and "abnormal" (Foucault 1999) elites; the defence of motherhood and the traditional family, forcing women to play the role of mothers; the legislative strategies within the frame of government populism; the strong alliance with the Catholic Church, which was historical in Italy and inaugurated on the transition to post-socialism in Poland. We argue that the populist inflection of the backlash aims precisely at defeating women's achievements of the last decades in terms of reproductive rights and citizenship, in a specific historical period in which reproduction - of bodies, subjectivities, natural resources, community and life in general - has become the field of the new process of accumulation by the neoliberal heteropatriarchy (Federici 2012). This goal is pursued by controlling women's self-determination, both for their reproductive power and for their resistance potential in community and social relationships.

\footnotetext{
27 "Faced with the increase of cases of objection, obstetric violence and general misinformation on medical / health practices concerning women and LGBTQI subjects, we felt the need to create a self-managed platform that will allow us to denounce the places where the objection of conscience is applied, and at the same time to offer a free access service to information that are not commonly available (services, opening hours, etc.) (...). For this reason, we decided to create this map, where our experiences and our knowledge are put at the service of all, in a path that wants to sanction all those places that deprive us of the right to choose and self-determine" (Obiezione Respinta 2017b).
} 
This latter point has become the main anti-gender goal in the very recent years, revealing to be the real and final battle of the anti-gender war worldwide. In this new phase, all previous anti-gender discursive and political strategies are assembled and polarised: in fact, the final attack on abortion is based on the heteropatriarchal defence of the traditional family and the moral imperative of heterosexual reproduction, thereby fuelling homo- and transphobia as well as misogyny, through the degradation of women's social role to that of mothers, deprived of full political subjectivity and citizenship. All these issues concern the fundamental questions of how, why and who produces laws that colonise women's bodies, affecting women's sovereignty over their own subjectivities.

If the conflict on abortions in Poland and Italy show different genealogies, at the same time we can see a significant convergence concerning the virulent spread of anti-gender and pro-life forces, and the explosion of the transnational movement called Ni Una Menos. In this sense, it is worth noting that the worldwide movement started in Poland precisely with the launch of the women's strike against the ban on abortions, in alliance with the Argentinian movement against femicide, highlighting the strong connection between gender-based violence and state's control over women's bodies.

Considering the ban on abortion as a form of gender-based violence, the transnational feminist movement framed a new feminist radical conceptualisation of the relationship between production and reproduction within the intersection of neoliberalism and neofundamentalism (Zappino 2016, Bellè et al. 2018), for which sexual violence lies at the heart of capitalistic accumulation through women's obligation to reproduce (Federici 2012, 2019). The movement denounces the plot of sexism, the exploitation and the control of bodies operated by the austerity policies, as well as the racist and classist borders erected between and within countries, and the restriction of the spaces of women's self-determination.

Therefore, the aim of the feminist movement through the practice of strikes is to subvert the alignment to the social and economic norms based on the heteropatriarchal hierarchy of genders in the job market and society as a whole - thus making visible the relevance and at the same time the forced invisibilisation of women's work in social reproduction (Mason-Deese 2018). This has led to the reprise of social mutualism and self-help as a way of resisting the backlash policies, but also to create alternative relationships of feminist solidarity, especially in the field of reproductive rights. The feminist strike is, therefore, a social and political process of subjectivation by refusing to reproduce the heteronormative society and its moral obligations.

In Italy and Poland, these political repertoires have been practiced by feminist movements according to each specific national context. From one side, they have different strategies in the use of law: more intense in the Polish movement and more sceptical in the Italian one, where the preference was to create a sort of "normativity from below" with the drafting of the Feminist Plan against male violence against women and gender-based violence. From the other side, solidarity and mutualistic practices characterise both movements, not only to overcome the formal or actual limits to the right to an abortion, but also in order to build fixed and alternative relationships concerning reproductive self-determination. The feminist strike is a social and political 
process of subjectivation by refusing to reproduce the heteronormative society and its moral obligations

Thanks to these movements, new perspectives and alliances are now arising globally, concerning reproduction as a wider concept related to situated and political relationships, community bonds, and ecology (Federici 2012, Gago and Mason-Deese 2019), giving breath to the possibility of really subverting the heteropatriarchal and neoliberal exploitation of bodies and life.

Hence, we would argue that this movement addresses not only single national or international issues, but it is globally challenging a neoliberal paradigm of law and citizenship, as well as its epistemological, political, juridical and economic boundaries, through the practices of solidarity, recognition, sisterhood and a new possible dimension of resistance.

\section{References}

Autorino, T., Mattioli, F., and Mencarini, L., 2018. The Impact of Gynecologists' Conscientious Objection on Access to Abortion in Italy. WP Dondena [online], $\mathrm{n}^{\mathrm{o}}$ 119, Università Bocconi. Available from:

https://www.dondena.unibocconi.it/wps/wcm/connect/cdr/centro dondena/hom e/working+papers/working+paper+no.+119 [Accessed 4 September 2020].

Bellè, E., Peroni, C., and Rapetti, E., 2018. One step up and two steps back? The Italian debate on secularization, heteronormativity and LGBTQI citizenship. Social Compass [online], 65(5), 591-607. Available from: https://doi.org/10.1177/0037768618800750 [Accessed 4 September 2020].

Bennett, W.L., and Segerberg, A., 2012. The logic of connective action: Digital media and the personalization of contentious politics. Information, communication $\mathcal{E}$ society [online], 15(5), 739-768. Available from: https://doi.org/10.1080/1369118X.2012.670661 [Accessed 4 September 2020].

Bonfiglioli, C., 2011. Former East, Former West: Post-Socialist Nostalgia and Feminist Genealogies in Today's Europe. Glasnik Etnografskog Instituta SANU [online], 59(1), 115-128. Available from: https://doi.org/10.2298/GEI1101115B [Accessed 4 September 2020].

Bracke, M.A., 2017. Feminism, the state, and the centrality of reproduction: abortion struggles in 1970s Italy. Social History [online], 42(4), 524-546. Available from: https://doi.org/10.1080/03071022.2017.1368234 [Accessed 4 September 2020].

Braidotti, R., 2008. In spite of the times: The postsecular turn in feminism. Theory, Culture $\mathcal{E}$ Society [online], 25(6), 1-24. Available from: https://doi.org/10.1177/0263276408095542 [Accessed 4 September 2020].

Buss, D., and Herman, D., 2003. Globalizing Family Values: The Christian Right in International Politics. Minneapolis/London: University of Minnesota Press.

Calloni, M., 2001. Debates and Controversies on Abortion in Italy. In: D. McBride Stetson, ed., Abortion Politics, Women's Movements, and the Democratic State. Oxford University Press, 181-204. 
Cigarini, L., 1994. La politica del desiderio. Parma: Pratiche.

Dalla Costa, M.R., 1988. Domestic labour and the feminist movement in Italy since the 1970s. International Sociology [online], 3(1), 23-34. Available from: https://doi.org/10.1177/026858088003001002 [Accessed 4 September 2020].

Datta, N., 2018. Restoring the Natural Order: The Religious Extremists' Vision to Mobilize European Societies against Human Rights on Sexuality and Reproduction [online]. Brussels: European Parliamentary Forum on Population \& Development (Vol. 14). Available from: https://www.epfweb.org/sites/default/files/202005/rtno epf book lores.pdf [Accessed 4 September 2020].

Federici, S., 2012. Revolution at Point Zero: Housework, Reproduction, and Feminist Struggle. Oakland: PM Press.

Federici, S., 2019. On reproduction as an interpretative framework for social/gender relations, Gender, Place \& Culture. A Journal of Feminist Geography [online], 25 (9), 1391-1396. Available from:

https://www.tandfonline.com/doi/full/10.1080/0966369X.2018.1552404?scroll=top \&needAccess=true [Accessed 11 September 2020].

Figà-Talamanca, I., Grandolfo, M.E., and Spinelli, A., 1986. Epidemiology of legal abortion in Italy. International Journal of Epidemiology [online], 15(3), 343-351. Available from: https://doi.org/10.1093/ije/15.3.343 [Accessed 4 September 2020].

Fotopoulou, A., 2016. Feminist Activism and Digital Networks: Between Empowerment and Vulnerability. London: Palgrave Macmillan.

Foucault, M., 1999. 1974-1975. Les anormaux: Cours au Collège de France. Paris: Le Seuil.

Gago, V., and Mason-Deese, L., 2019. Eight Theses on the Feminist Revolution. Toward Freedom [online], 10 September. Available from:

https://towardfreedom.org/story/eight-theses-on-the-feminist-revolution/ [Accessed 4 September 2020].

Gal, S., and Kligman, G., 2000. The Politics of Gender after Socialism: A ComparativeHistorical Essay. Princeton University Press.

Garbagnoli, S., 2014. “L'ideologia del genere”: L'irresistibile ascesa di un'invenzione retorica vaticana contro la denaturalizzazione dell'ordine sessuale. About Gender [online], 3(6), 250-263. Available from: https://doi.org/10.15167/22795057/ag.2014.3.6.224 [Accessed 4 September 2020].

Garbagnoli, S., 2017. Italy as a Lighthouse: Antigender protests between the "anthropological question" and national identity. In: R. Kuhar and D. Paternotte, eds., Anti-Gender Campaigns in Europe Mobilizing against Equality. London/New York: Rowman and Littlefield.

Garbagnoli, S., and Prearo, M., 2017. La croisade "anti-genre": Du Vatican aux manifs pour tous. Paris : Textuel, coll. Petite encyclopédie critique.

Grabowska, M., 2009. Polish feminism between east and west: The formation of the polish women's movement identity [online]. Dissertation for the degree of Doctor of Philosophy Graduate Program in Women's and Gender Studies. Written under 
the direction of Professor Joanna Regulska. New Brunswick: Rutgers University. Available from: https://rucore.libraries.rutgers.edu/rutgers-lib/26287/PDF/1/play/ [Accessed 4 September 2020].

Grabowska, M., 2012. Bringing the Second World in: Conservative revolution (s), socialist legacies, and transnational silences in the trajectories of Polish feminism. Signs: Journal of Women in Culture and Society [online], 37(2), 385-411. Available from: https://doi.org/10.1086/661728 [Accessed 4 September 2020].

Grabowska, M., 2014. Cultural war or "business as usual"? Recent instances, and the historical origins, of a "backlash" against women's and sexual rights in Poland [online]. Warsaw: Heinrich Böll Stiftung. Available from:

https://pl.boell.org/sites/default/files/uploads/2014/10/cultural_war_or_grabowsk a.pdf [Accessed 4 September 2020].

Graff, A., 2003. Lost between the Waves? The Paradoxes of Feminist Chronology and Activism in Contemporary Poland. Journal of International Women's Studies [online], 4(2), 100-116. Available from: https://vc.bridgew.edu/jiws/vol4/iss2/9/ [Accessed 4 September 2020].

Graff, A., 2010. Efekt magmy, czyli o szczególnej roli Kościoła katolickiego w Polsce. In: A. Ostolski, ed., Kościót, państwo i polityka ptci [online]. Warsaw: Fundacja im. Heinricha Bölla w Polsce, 10-25. Available from: https://pl.boell.org/sites/default/files/kosciol_panstwo_i_polityka_plci.pdf [Accessed 4 September 2020].

Graff, A., 2014. Report from the gender trenches: War against "genderism" in Poland. European Journal of Women's Studies [online], 21(4), 431-435. Available from: https://doi.org/10.1177/1350506814546091 [Accessed 4 September 2020].

Gunnarsson-Payne, J., 2019. Kobiety jako "lud". Czarne Protesty jako sprzeciw wobec autorytarnego populizmu w perspektywie międzynarodowej. In: E. Korolczuk et al., eds., Bunt kobiet: Czarne protesty i strajki kobiet [online]. Gdansk: Europejskie Centrum Solidarności, 55-183. Available from: https://ecs.gda.pl/library/File/nauka/e-booki/raport/ECS raport buntkobiet.pdf [Accessed 4 September 2020].

Hall, B., 2019. Gendering resistance to right-wing populism: Black protest and a new wave of feminist activism in Poland? American behavioral scientist [online], 63(10), 1497-1515. Available from: https://doi.org/10.1177/0002764219831731 [Accessed 4 September 2020].

Hanafin, P., 2007. Conceiving Life: Reproductive Politics and the Law in Contemporary Italy. Aldershot: Ashgate.

Herdt, G., 2009. Moral Panics, Sexual Panics: Fear and the Fight over Sexual Rights. New York University Press.

Komisja Polityki Społecznej i Rodziny nr46, z dnia 3 listopada 2016 r., Biuletyn nr 1188/VIII [Social Policy and Family Committee no 46 from 3 November 2016, Bulletin no 1188/VIII] [online]. Available from:

http://orka.sejm.gov.pl/Zapisy8.nsf/wgskrnr/PSR-46 [Accessed 4 September 2020]. 
Korolczuk, E., 2016. Explaining mass protests against abortion ban in Poland: the power of connective action. Zoon politikon [online], 7, 91-113. Available from: https://www.civitas.edu.pl/wpcontent/uploads/2015/03/Zoon_Politikon_07 2016 091 113.pdf [Accessed 4 September 2020].

Kováts, E., and Põim, M., eds., 2015. Gender as Symbolic Glue: The Position and Role of Conservative and Far Right Parties in the Anti-Gender Mobilizations in Europe [online]. FEPS-Foundation for European Progressive Studies/Friedrich-EbertStiftung. Available from: https://library.fes.de/pdffiles/bueros/budapest/11382.pdf [Accessed 4 September 2020].

Kuhar, R., and Paternotte, D., eds., 2017. Anti-Gender Campaigns in Europe Mobilizing against Equality. London/New York: Rowman and Littlefield.

Kulczycki, A., 1995. Abortion Policy in Post-communist Europe: The Conflict in Poland. Population and Development Review [online], 21(3). Available from: https://doi.org/10.2307/2137747 [Accessed 4 September 2020].

Lavizzari, A., and Prearo, M., 2018. The anti-gender movement in Italy: Catholic participation between electoral and protest politics. European Societies [online], 21(3). Available from: https://doi.org/10.1080/14616696.2018.1536801 [Accessed 4 September 2020].

Libreria delle donne di Milano, 1986. Non credere di avere dei diritti. Turin: Rosenberg \& Sellier.

Majewska, E., 2016. Słaby opór i siła bezsilnych. \#Czarnyprotest kobiet w Polsce 2016. [Weak resistance and the power of the powerless. Women's \#Blackprotest in Poland 2016]. Praktyka Teoretyczna [online]. Available from:

https://www.academia.edu/31140128/Słaby opór_i siła bezsilnych_Czarny prot est kobiet w Polsce 2016 [Accessed 4 September 2020].

Mason-Deese, L., 2018. From \#MeToo to \#WeStrike: a politics in feminine. Where Freedom Starts: Sex Power Violence\# MeToo. Versobook Blog [online], 6 March. Available from: https://www.versobooks.com/blogs/3666-from-metoo-towestrike-a-politics-in-feminine [Accessed 4 September 2020].

Mény, Y., and Surel, Y., 2002. The constitutive ambiguity of populism. In: Y. Mény and Y. Surel, eds., Democracies and the populist challenge [online]. London: Palgrave Macmillan, 1-21. Available from: https://doi.org/10.1057/9781403920072 1 [Accessed 4 September 2020].

Ministero della Salute, 2017. Relazione del Ministro della Salute sulla attuazione della legge contenente norme per la tutela sociale della maternità e dell'interruzione volontaria di gravidanza (Legge 194/78) [Report on the application of Law 194/78. Protection on maternity and abortion] (online). Rome, 22 December. Available from: http://www.salute.gov.it/imgs/C 17 pubblicazioni_2686_allegato.pdf [Accessed 11 September 2020].

Ministero della Salute, 2018. Relazione del Ministro della Salute sulla attuazione della legge contenente norme per la tutela sociale della maternità e dell'interruzione volontaria di gravidanza (Legge 194/78) [Report on the application of Law 194/78. Protection on 
maternity and abortion] (online). Available from:

http://www.salute.gov.it/imgs/C 17 pubblicazioni_2807_allegato.pdf [Accessed 11 September 2020].

Munro, E., 2013. Feminism: A Fourth Wave? Political Insight [online], 4(2), 22-25. Available from: https://doi.org/10.1111/2041-9066.12021 [Accessed 4 September 2020].

Non Una Di Meno, 2017a. 8 punti per Lottomarzo. Nonunadimeno [online], 18 February. Available from: https://nonunadimeno.wordpress.com/2017/02/18/8punti-per-lottomarzo/ [Accessed 11 September 2020].

Non Una Di Meno, 2017b. Abbiamo un Piano: Piano femminista contro la violenza maschile sulle donne e la violenza di genere. Nonunadimeno [online], November. Available from:

https://nonunadimeno.files.wordpress.com/2017/11/abbiamo_un_piano.pdf [Accessed 4 September 2020].

Non Una Di Meno, 2018. Appello nazionale di Non Una di Meno verso i 40 anni dalla Legge 194. [Blog post]. Nonunadimeno [online], 12 May. Available from: https://nonunadimeno.wordpress.com/2018/05/12/appello-nazionale-di-non-unadi-meno-verso-i-40-anni-dalla-legge-194/ [Accessed 4 September 2020].

Obiezione Respinta, 2017a. SoS Aborto! Obiezionerespinta [online]. Available from: https://obiezionerespinta.info/campagna sos aborto/ [Accessed 4 September 2020].

Obiezione Respinta, 2017b. Sui nostri corpi, sulla nostra salute e sul nostro piacere decidiamo noi! [Manifesto]. Obiezionerespinta [online]. Available from: https://obiezionerespinta.info/manifesto/ [Accessed 4 September 2020].

Ozzano, L., and Giorgi, A., 2015. European Culture Wars and the Italian Case: Which Side Are You On? London: Routledge.

Paternotte, D., and Kuhar, R., 2018. Disentangling and Locating the "Global Right": Anti-Gender Campaigns in Europe. Politics and Governance [online], 6(3), 6-19. Available from: https://doi.org/10.17645/pag.v6i3.1557 [Accessed 4 September 2020].

Pavan, E., and Mainardi, A., 2018. Striking, Marching, Tweeting. Studying how online networks change together with movements. Partecipazione e conflitto [online], 11(2), 394-422. Available from: http://dx.doi.org/10.1285\%2Fi20356609v11i2p394 [Accessed 4 September 2020].

Peroni, C., 2015. Gender-Based Violence and "Feminicide" in Queer Italian Movements: Questioning Gender, Sexuality, and the (Hetero) Normative Order. Oñati Socio-Legal Series [online], 5(6). Available from: http://opo.iisj.net/index.php/osls/article/view/499 [Accessed 11 September 2020].

Peroni, C., 2018. Il \#MeToo di Hollywood e il \#WeToogether di Non Una Di Meno. Dalla denuncia alla pratica collettiva contro le molestie sessuali nel/del lavoro. In: M. Bettaglio, N. Mandolini and S. Ross, eds., Rappresentare la violenza di genere: 
Sguardi femministi sulla letteratura, il cinema, il teatro e il discorso mediatico contemporaneo. Milan: Mimesis.

Pitch, T., 1998. Un diritto per due: La costruzione giuridica di genere, sesso e sessualità. Rome: Il Saggiatore.

Ramet, S.P., 2014. The Catholic Church in Post-Communist Poland: Polarization, Privatization, and Decline in Influence. In: S.P. Ramet, Religion and Politics in Post-Socialist Central and South-eastern Europe. London: Palgrave Macmillan.

Richardson, D., 2017. Rethinking sexual citizenship. Sociology [online] 51(2), 208-224. Available from: https://journals.sagepub.com/doi/full/10.1177/0038038515609024 [Accessed 11 September 2020].

Salvatori, L., 2018. "Lost Between the Waves" or Riding a New Tide? Drawing Connections Between Italian and Polish Digitally Mediated Feminism. Studies in Russian, Eurasian and Central European New Media [online], 19, 73-91. Available from: https://www.digitalicons.org/wpcontent/uploads/2019/02/DI19 4 Salvatori.pdf [Accessed 4 September 2020].

Scott, J.W., 2009. Sexularism. Paper presented at RSCAS Distinguished Lectures, Robert Schuman Centre for Advanced Studies. Florence, 23 April.

Seidman, S., 2001. From identity to queer politics: Shifts in normative heterosexuality and the meaning of citizenship. Citizenship Studies [online], 5(3), 321-328.

Available from:

https://www.tandfonline.com/doi/abs/10.1080/13621020120085270 [Accessed 11 September 2020].

Strajk Kobiet, 2017. Co Robimy. Strajk Kobiet [online]. Available from: http://strajkkobiet.eu/co-robimy/ [Accessed 4 September 2020].

Szelewa, D., 2016. Killing “Unborn Children”? The Catholic Church and Abortion Law in Poland Since 1989. Social \& Legal Studies [online], 25(6), 741-764. Available from: https://doi.org/10.1177/0964663916668247 [Accessed 4 September 2020].

Urquhart, G., 1999. The Pope's Armada: Unlocking the Secrets of Mysterious and Powerful New Sects in the Church. Amherst: Prometheus Books.

Valentini, C., 1997. Le donne fanno paura. Rome: Il Saggiatore.

Wodak, R., 2015. The Politics of Fear: What Right-Wing Populist Discourses Mean. London: Sage.

Zappino, F., ed., 2016. Il genere tra neoliberismo e neofondamentalismo. Verona: Ombre Corte. 